\title{
Dynamics of the microfauna community in a full-scale municipal wastewater treatment plant experiencing sludge bulking
}

\author{
Bo Hu${ }^{\mathrm{a}}$, Rong Qi ${ }^{\mathrm{a}}$, Wei An ${ }^{\mathrm{a}}$, Muqi Xu ${ }^{\mathrm{b}}$, Yu Zhang ${ }^{\mathrm{a}}$, Xue Bai ${ }^{\mathrm{c}}$, Haipeng Bao ${ }^{\mathrm{c}}$, Yang Wen ${ }^{\mathrm{c}}$, \\ Jian $\mathrm{Gu}^{\mathrm{c}}$, Min Yang ${ }^{\mathrm{a}, *}$ \\ a State Key Laboratory of Environmental Aquatic Chemistry, Research Center for Eco-Environmental Sciences, Chinese Academy of Sciences, \\ Beijing 100085, China \\ ${ }^{\mathrm{b}}$ Key Laboratory of Animal Ecology and Conservation Biology, Institute of Zoology, Chinese Academy of Sciences, Beijing 100101, China \\ ${ }^{\mathrm{c}}$ Beijing Drainage Group Co., Ltd., Beijing 100044, China
}

Received 5 October 2012; received in revised form 13 March 2013; accepted 29 March 2013

Available online 28 April 2013

\begin{abstract}
We investigated the dynamics of the microfauna community in activated sludge, with special reference to sludge bulking, in two parallel municipal wastewater treatment systems in Beijing, China over a period of 14 months. Annual cyclic changes in microfauna community structures occurred in both systems. RELATE analysis based on Spearman's Rank correlation indicated that microfauna community structures were highly correlated with the sludge volume index (SVI) $(p<0.001)$, which indicates sludge settleability. Nutrient conditions of raw sewage $(p<0.01)$ and hydraulic retention time (HRT) $(p<0.05)$ were also related to microfauna community structures. Abundances of the species Epistylis plicatilis and Vorticella striata increased significantly with an increase in SVI $(p<0.001)$ and decrease in water temperature $(p<0.001)$, suggesting that sludge bulking may have created favorable conditions for the two species, even under unfavorable temperature conditions. Sludge de-flocculation primarily due to the excessive growth of Microthrix parvicella-like filaments could be an important driving force for the microfauna community changes. The release of flocculated non-filamentous bacteria may represent a suitable food source for these species. The two species may be considered as potential bioindicators for sludge bulking.
\end{abstract}

(c) 2013 Elsevier GmbH. All rights reserved.

Keywords: Activated sludge; Bioindicators; Micro-metazoans; Municipal wastewater; Protozoan microfauna; Sludge bulking

\section{Introduction}

Biological wastewater treatment relies on the collective action of different organisms present in treatment systems (Madoni 1994; Martins et al. 2004; Pauli et al. 2001). While bacteria play a key role in pollutant transformation and removal, microfauna (consisting of protozoa and micrometazoa), as the main consumers of various particles in

\footnotetext{
*Corresponding author. Tel.: +8610 62923475; fax: +861062923541.

E-mail address: yangmin@rcees.ac.cn (M. Yang).
}

wastewater, also affect the treatment performance through their predation (Curds 1982; Woombs and Laybourn-Parry 1986) and excretion of compounds stimulating bacterial growth (Ratsak et al. 1996; Shen et al. 1990) and promoting bacterial flocculation (Curds 1982; Pauli et al. 2001). Insight into microfauna community composition is of great significance for a holistic understanding of activated sludge ecosystems. Secondly, because of the distinct relations between microfauna, the environment and the operability (Curds and Cockburn 1970; Drzewicki and Kulikowska 2011; Dubber and Gray 2011; Madoni 1994; Salvadó et al. 2004), microfauna has been used as performance 
bioindicators for biological wastewater treatment systems (BWTSs).

Changes in the bacterial community in BWTSs can lead to serious deleterious problems. Sludge bulking, a phenomenon associated with the deterioration of sludge settleability, has long been a challenge for BWTSs. Recent evidence suggests that the abnormal growth of some filamentous bacteria is responsible for most sludge bulking and foaming problems encountered in BWTSs (Horan et al. 2004; Jenkins et al. 2003; Martins et al. 2004; Rossetti et al. 2005). Since bacteria are the primary food source for most microfauna species in BWTSs (Shen et al. 1990; Woombs and LaybournParry 1986), changes in bacterial communities (in terms of species composition and morphology) may have the potential to cause significant changes in microfauna communities. Although some microfauna species have been found to be associated with sludge-bulking (Esteban et al. 1991; Lee et al. 2004; Martín-Cereceda et al. 1996), the impact of sludge conditions on microfauna community structure has not yet been systematically studied.

We monitored the dynamics of microfauna communities in two parallel full-scale municipal wastewater treatment systems in a plant located in Beijing, China, continuously over a period of 14 months, which covered an entire sludge bulking period; sludge bulking occurred in the two systems, beginning from January and ending in June, for three consecutive years prior to the present study. Results were analyzed using a series of multivariate analysis approaches. The objectives of our study were: (1) to reveal the dynamics of the microfauna community during sludge bulking and (2) to identify sensitive microfauna species, which are closely related to sludge settleability and may be potentially used as bioindicators for sludge bulking. The knowledge acquired during this study should contribute toward better management of activated sludge processes.

\section{Material and Methods}

\section{Description of the systems investigated}

The investigated municipal wastewater treatment plant consists of a conventional $\mathrm{A}^{2} / \mathrm{O}$ system (System A: anaerobic/anoxic/aerobic) and an inverted $\mathrm{A}^{2} / \mathrm{O}$ system (System $\mathrm{B}$ : anoxic/anaerobic/aerobic), each of which has a treatment capacity of $200,000 \mathrm{~m}^{3} \mathrm{day}^{-1}$. The sludge recycling ratio was approximately $100 \%$ for both systems, while the mixed liquor recirculation ratio was $250 \%$ for System A and none for System B. In System B, the influent was distributed into the anoxic and anaerobic tanks at a ratio of 3:7. Detailed descriptions of the two systems were provided by Qi et al. (2012). In the past 3 years, each system received mean wastewater flows of $225,000 \mathrm{~m}^{3}$ day $^{-1}$ and exhibited sludge bulking mainly from January to May; system B exhibited more serious bulking.
For solids' residence time (SRT), hydraulic retention time (HRT) and other operational parameters, see Table 1.

\section{Sample collection}

Mixed liquor samples for microfauna analysis in each system were collected from the end of the aeration tanks during 7 July 2009 to 10 September 2010. Sampling intervals were mostly 2 or 3 weeks, except for the intervals between the first three samples in each system, which were longer (Table S1). The samples were kept in suspension using a portable air pump until the completion of analysis. Samples from System A were taken one day after System B, so as to ensure that each sample could be analyzed in a timely manner.

\section{Microscopic examination}

Identification and enumeration of microfauna using brightfield and differential interference contrast microscopy were performed within $5 \mathrm{~h}$ after sample collection (Madoni and Ghetti 1981). Protozoa were identified mostly to the species level, mainly based on morphology and movement in live observations, according to several keys (Foissner et al. 1999; Kudo 1966; Patterson 1996; Shen et al. 1990). Micrometazoa were grouped into four classes (Rotifera, Nematoda, Gastrotricha and Tardigrada). Microfauna enumeration was performed using two different methods. After shaking, subsamples of $25 \mu \mathrm{L}$ were utilized for microscopic analysis with three replicates (Martín-Cereceda et al. 1996). Protozoa (except single-living small flagellates) and micro-metazoa were both counted. A Neubauer counting plate with a counting chamber of $1 \times 1 \times 0.1$ (depth) mm was used for enumeration of single-living small flagellates $(\leq 10 \mu \mathrm{m}$ : for example, Bodo and Monas). After shaking, a 100- $\mu \mathrm{L}$ subsample of the mixed liquor was dispensed into the counting chamber and then tightly covered with a coverslip. Five replicates of all single-living small flagellates were counted, and the mean was calculated. Specimens not detected during counting but observed in screening were recorded as 1 individual $\mathrm{mL}^{-1}$ (Madoni 1994). Microfauna counts (individuals $\mathrm{mL}^{-1}$ ) were transformed into individual numbers per $\mathrm{g}$ mixed liquor suspended solids (MLSS) before statistical analysis.

Staining methods (Gram staining and Neisser staining) for facilitating the observations of filamentous bacteria and activated sludge flocs were performed according to Jenkins et al. (2003).

\section{Physico-chemical and operational parameters}

Water quality and sludge parameters were determined according to standard methods (APHA 1998) on a daily basis. Influent nutrient concentrations were converted to loadings. Values of some important parameters are shown in Table 1. Metal ions $\left(\mathrm{Na}^{+}, \mathrm{K}^{+}, \mathrm{Ca}^{2+}\right.$ and $\mathrm{Mg}^{2+}$, which may be relevant to sludge de-flocculation) of some samples were determined 
Table 1. Parameter characteristics of systems A and B investigated in this study.

\begin{tabular}{|c|c|c|c|c|c|c|c|c|c|}
\hline \multirow[t]{2}{*}{ Variable type } & \multirow[t]{2}{*}{ Variable } & \multicolumn{4}{|l|}{ System A } & \multicolumn{4}{|l|}{ System B } \\
\hline & & Avg & Std & Max & Min & Avg & Std & Max & Min \\
\hline Sludge characteristics & $\mathrm{SVI}\left(\mathrm{mL} \mathrm{g}^{-1}\right)$ & 115 & 52 & 256 & 45 & 141 & 69 & 310 & 50 \\
\hline \multirow[t]{3}{*}{ Operational parameters } & HRT (h) & 13.7 & 1.0 & 21.3 & 10.5 & 12.1 & 1.0 & 17.6 & 10.3 \\
\hline & SRT (day) & 14.3 & 5.9 & 45.3 & 5.3 & 8.7 & 3.5 & 33.0 & 3.9 \\
\hline & $\mathrm{DO}\left(\mathrm{mg} \mathrm{L}^{-1}\right)$ & 1.62 & 0.70 & 4.40 & 0.13 & 1.66 & 1.29 & 6.89 & 0.02 \\
\hline \multirow[t]{7}{*}{ Influent characteristics } & $\mathrm{T}\left({ }^{\circ} \mathrm{C}\right)$ & 21.1 & 4.4 & 26.7 & 14.0 & 21.1 & 4.4 & 26.7 & 14.0 \\
\hline & $\begin{array}{l}\text { BOD }_{5} \text { loading }(\mathrm{g} \\
\left(\mathrm{g} \mathrm{MLSS}^{-1} \mathrm{day}^{-1}\right)\end{array}$ & 0.08 & 0.02 & 0.15 & 0.03 & 0.11 & 0.03 & 0.22 & 0.03 \\
\hline & $\begin{array}{l}\text { TKN loading (g } \\
\left.(\mathrm{g} \mathrm{MLSS})^{-1} \mathrm{day}^{-1}\right)\end{array}$ & 0.026 & 0.005 & 0.047 & 0.012 & 0.034 & 0.008 & 0.079 & 0.013 \\
\hline & $\begin{array}{l}\text { TP loading }(\mathrm{g} \\
\left.\left(\mathrm{g}^{\mathrm{M} L S S}\right)^{-1} \mathrm{day}^{-1}\right)\end{array}$ & 0.0025 & 0.0006 & 0.0049 & 0.0010 & 0.0032 & 0.0008 & 0.0064 & 0.0013 \\
\hline & $\mathrm{C} / \mathrm{N}$ & 7.2 & 1.5 & 19.1 & 2.7 & 7.2 & 1.5 & 19.1 & 2.7 \\
\hline & $\mathrm{N} / \mathrm{P}$ & 10.6 & 1.6 & 17.8 & 6.6 & 10.6 & 1.6 & 17.8 & 6.6 \\
\hline & $\mathrm{C} / \mathrm{P}$ & 75.8 & 14.1 & 153.3 & 33.9 & 75.7 & 14.1 & 153.3 & 33.9 \\
\hline
\end{tabular}

Avg: average; Std: standard deviation; Max: maximum; Min: minimum. SVI: sludge volume index; HRT: hydraulic retention time; SRT: solids' residence time; DO: dissolved oxygen; T: water temperature; BOD $_{5}$ : five-day biochemical oxygen demand; TKN: total Kjeldahl nitrogen; TP: total phosphorus; MLSS: mixed liquor suspended solids; $\mathrm{C} / \mathrm{N}$ : chemical oxygen demand with dichromate/total Kjeldahl nitrogen; N/P: total Kjeldahl nitrogen/total phosphorus; and C/P: chemical oxygen demand with dichromate/total phosphorus. Data duration (beginning from 1 month before the first microfauna sampling, ending at the last sampling day): from 9 June, 2009 to 10 September, 2010 for System A; from 8 June, 2009 to 9 September, 2010 for System B.

using inductively coupled plasma optical emission spectrometry (ICP-OES) (PerkinElmer, USA).

\section{Statistical analysis}

For weighting contributions of common and rare species and stabilizing variance (Clarke and Warwick 2001), microfauna abundance data were fourth-root transformed; environmental variable data were log-transformed and normalized. Forward 30-day average environmental data were used when correlating environmental conditions with the total microfauna communities, since the total communities are considered not to react quickly to environmental variations (i.e., monthly averaged data may be more suitable than daily values; Curds and Cockburn 1970). The correlation analysis also suggested that monthly averaged data were more closely related than the daily values to the holistic changes of the microfauna community (unpublished data). Forward 48-h average environmental data were used when correlating environmental conditions with single microfauna species, since the generation times of microfauna are generally short (Shen et al. 1990; Sudo and Aiba 1984). Environmental variables used in our analysis are listed in Table 1.

Sludge conditions were classified into three categories according to the monthly averaged SVI (sludge volume index) values: normal ( $\left.\mathrm{SVI} \leq 120 \mathrm{mLg}^{-1}\right)$, transient $\left(120 \mathrm{~mL} \mathrm{~g}^{-1}<\mathrm{SVI}<180 \mathrm{~mL} \mathrm{~g}^{-1}\right)$ and sludge bulking $\left(\mathrm{SVI} \geq 180 \mathrm{~mL} \mathrm{~g}^{-1}\right.$ ) (Kruit et al. 2002; Martins et al. 2004; Parker 1983). To analyze changes in microfauna communities in relation to environmental variables, procedures of Cluster, SIMPROF (similarity profiles), NMDS (non-metric multi-dimensional scaling), Cyclicity tests, ANOSIM (analysis of similarities) and RELATE were carried out using PRIMER version 6.1 (Clarke and Gorley 2006). The Bray-Curtis coefficient was used to assess the community similarity of the microfauna; environmental similarity was measured using Euclidean distance. To analyze variations in single microfauna species (or taxa) and their relationship with environmental conditions, one-way ANOVA (analysis of variance) and Pearson correlation coefficients were calculated using STATISTICA Version 8.0. Post hoc comparisons were applied using the Spjotvoll/Stoline test (Tukey HSD for unequal $N$-test) method. Redundancy analysis (RDA) for illustrating the relationship between species composition and multivariate environmental variables was carried out using CANOCO version 4.5 (Lepš and Šmilauer 2003).

\section{Results}

\section{Changes in microfauna community structures}

The microfauna community structure is represented by the presence of each species (unit) and its abundance (individual $\left.(\mathrm{g} \mathrm{MLSS})^{-1}\right)$. Cluster analysis of the microfauna community structure together with SIMPROF tests based on Bray-Curtis similarity are presented in Fig. 1. Microfauna community structures of neighboring samples generally clustered together, showing the temporal changes in community structures. NMDS analysis results (Fig. 2) illustrated the holistic dynamics of the microfauna community in both systems, which were cyclic with a period of approximately one 


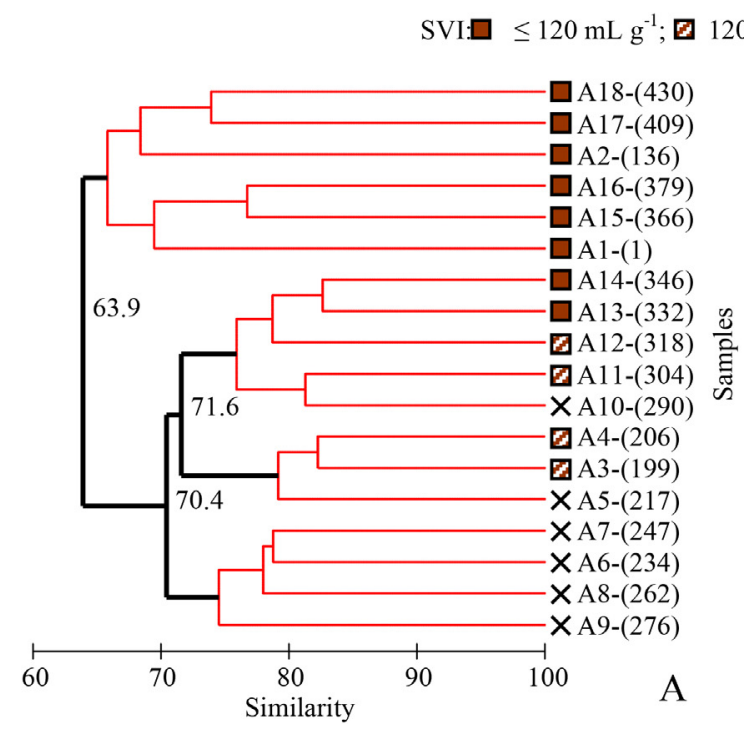

$120-180 \mathrm{~mL} \mathrm{~g}^{-1} ; \quad x \geq 180 \mathrm{~mL} \mathrm{~g}^{-1}$

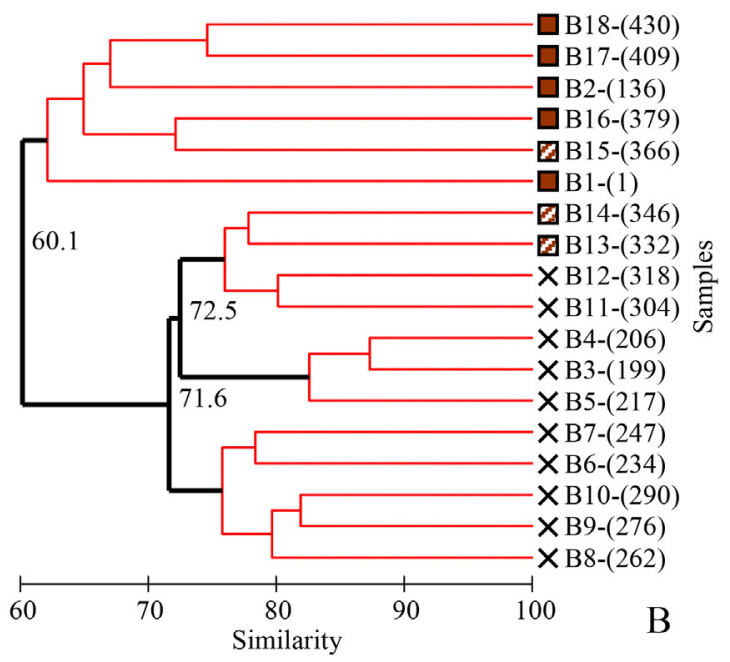

Fig. 1. Cluster and SIMPROF analysis: dendrograms of microfauna community structures in systems A (A) and B (B). SVI: sludge volume index. A1-A18: sample numbers in System A; and B1-B18: sample numbers in System B. Bold black lines indicate significant divergence between clusters $(p<0.05)$ and numbers alongside indicate similarities between branches. Numbers in round brackets indicate sampling day in each system. Classification of SVI levels was based on the monthly average SVI data.

SVI $\square \leq 120 \mathrm{~mL} \mathrm{~g}^{-1} ;$ 田 $120-180 \mathrm{~mL} \mathrm{~g}^{-1} ; \quad X \geq 180 \mathrm{~mL} \mathrm{~g}^{-1}$
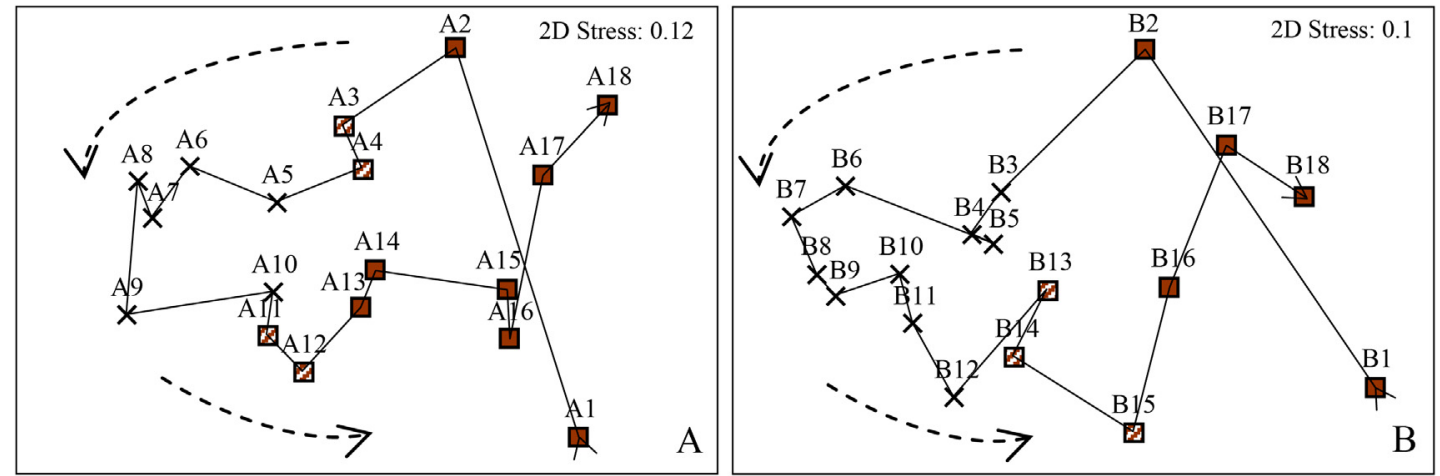

Fig. 2. NMDS analysis: trajectories of changes in microfauna community structure through time in systems A (A) and B (B). SVI: sludge volume index. A1-A18: sample numbers in System A; and B1-B18: sample numbers in System B. Classification of SVI levels was based on the monthly average SVI data.

year. Cyclicity tests (Clarke and Gorley 2006; Clarke and Warwick 2001) indicated that changes in microfauna community structures were significantly $(p<0.01)$ correlated to a 1 -year cyclical temporal variation model.

Secondly, apart from a few irregularities, microfauna community structures of sludge samples with a low SVI value (normal state, $\mathrm{SVI} \leq 120 \mathrm{~mL} \mathrm{~g}^{-1}$ ) were grouped together (Fig. 1), showing a significant difference $(p<0.05)$ compared to samples with medium (transient state, $120 \mathrm{~mL} \mathrm{~g}^{-1}<\mathrm{SVI}<180 \mathrm{~mL} \mathrm{~g}^{-1}$ ) or high SVI (sludge bulking state, $\mathrm{SVI} \geq 180 \mathrm{~mL} \mathrm{~g}^{-1}$ ) values in both systems. Similar results could also be obtained with the ANOSIM analysis, as shown in Table 2. Community structures of samples were clearly different among different sludge conditions. Significant $(p<0.05)$ and highly significant $(p<0.01)$ differences were observed between the medium and high SVI groups and between the low and high SVI groups, respectively.

\section{Correlations between microfauna community structures and environmental variables}

Results from RELATE analysis, indicating the relationship between microfauna community structures and environmental variables based on Spearman's Rank correlation, are summarized in Table 3. Changes in microfauna community structures were strongly correlated to the index reflecting the sludge settleability (i.e., SVI). This correlation in System B, which exhibited more serious sludge bulking, was higher than that in System A. 
Table 2. ANOSIM analysis of microfauna community structures among different sludge volume index (SVI) levels in systems A and B.

\begin{tabular}{|c|c|c|c|c|c|}
\hline \multirow[t]{2}{*}{ Test } & \multirow[t]{2}{*}{ SVI level } & \multicolumn{2}{|l|}{ System A } & \multicolumn{2}{|l|}{ System B } \\
\hline & & $R$ statistic & $p$ Value & $R$ statistic & $p$ Value \\
\hline Global test & Global & 0.422 & $0.0006^{* *}$ & 0.722 & $0.0001^{* *}$ \\
\hline \multirow[t]{3}{*}{ Pairwise test } & Low-high & 0.671 & $0.0007^{* *}$ & 0.922 & $0.0003^{* *}$ \\
\hline & Low-medium & 0.180 & 0.1390 & 0.426 & 0.0710 \\
\hline & High-medium & 0.425 & $0.0190^{*}$ & 0.507 & $0.0100^{*}$ \\
\hline
\end{tabular}

Classification of SVI levels was based on the monthly average SVI data: low $\left(\mathrm{SVI} \leq 120 \mathrm{~mL} \mathrm{~g}^{-1}\right)$; medium $\left(120 \mathrm{~mL} \mathrm{~g}^{-1}<\mathrm{SVI}<180 \mathrm{~mL} \mathrm{~g}-1\right)$; and high $\left(\mathrm{SVI} \geq 180 \mathrm{~mL} \mathrm{~g}^{-1}\right)$.

$$
\begin{array}{rl}
{ }^{*} p & <0.05 . \\
{ }^{* *} & p<0.01
\end{array}
$$

Influent characteristics were also significantly correlated with microfauna community structures, with water temperature exhibiting the greatest coefficients (Table 3). The loadings of $\mathrm{BOD}_{5}$ (five-day biochemical oxygen demand), TKN (total Kjeldahl nitrogen) and TP (total phosphorus) were significantly $(p<0.01)$ correlated to microfauna community structures with similar correlation coefficients (Table 3).

Among the three operational variables, i.e., HRT, SRT and DO (dissolved oxygen), only HRT were significantly $(p<0.05)$ related to the microfauna community structures in both systems (Table 3 ).

\section{Correlations between some microfauna species and environmental variables}

Eighty-three morphospecies, one morphologic unit (single-living small flagellates) and one systematic unit (Mayorella spp.) of protozoa, as well as four systematic units of micro-metazoa, were observed and recorded in the two systems during the study period (main species and their abundance variations relevant to the sludge settleability changes are shown in Table S2). Six species, including Epistylis plicatilis, Vorticella striata, Carchesium polypinum, Vorticella cupifera, Entosiphon sulcatum and Petalomonas mediocanellata, exhibited significant variations among different sludge conditions in both systems, according to the results from ANOVA analysis (Table 4, Table S2).

Results from RDA analysis, indicating relationships between the above six special species and environmental variables, are illustrated in Fig. 3. In System A, the first two ordination axes explained $66.5 \%$ of total variability in the species data and $91.1 \%$ of species-environment relations; in System B, the first two axes explained $70.0 \%$ of total variability in the species data and $91.2 \%$ of speciesenvironment relations. Pearson correlation coefficients between microfauna species abundances and environmental variables corresponding to the RDA analysis are shown in Table S3.

Table 3. RELATE analysis between microfauna community structures and environmental variables in systems A and B.

\begin{tabular}{|c|c|c|c|c|c|}
\hline \multirow[t]{2}{*}{ Variable type } & \multirow[t]{2}{*}{ Variable } & \multicolumn{2}{|l|}{ System A } & \multicolumn{2}{|l|}{ System B } \\
\hline & & Rho statistic & $p$ Value & Rho statistic & $p$ Value \\
\hline Sludge characteristics & SVI & 0.586 & $0.0001^{* * * *}$ & 0.739 & $0.0001^{* * * *}$ \\
\hline Operational parameters & $\begin{array}{l}\text { HRT } \\
\text { SRT } \\
\text { DO }\end{array}$ & $\begin{array}{l}0.365 \\
0.018 \\
0.109\end{array}$ & $\begin{array}{l}0.0020^{* *} \\
0.4094 \\
0.1942\end{array}$ & $\begin{array}{l}0.222 \\
0.273 \\
0.007\end{array}$ & $\begin{array}{l}0.0385^{*} \\
0.0293^{*} \\
0.4385\end{array}$ \\
\hline Influent characteristics & $\begin{array}{l}\mathrm{T} \\
\mathrm{BOD}_{5} \text { loading } \\
\text { TKN loading } \\
\text { TP loading } \\
\mathrm{C} / \mathrm{N} \\
\mathrm{N} / \mathrm{P} \\
\mathrm{C} / \mathrm{P}\end{array}$ & $\begin{array}{r}0.573 \\
0.410 \\
0.379 \\
0.440 \\
0.376 \\
0.188 \\
-0.080\end{array}$ & $\begin{array}{l}0.0001^{* * * *} \\
0.0015^{* *} \\
0.0023^{* *} \\
0.0004^{* * *} \\
0.0041^{* *} \\
0.0667 \\
0.7164\end{array}$ & $\begin{array}{l}0.576 \\
0.464 \\
0.389 \\
0.422 \\
0.440 \\
0.172 \\
0.002\end{array}$ & $\begin{array}{l}0.0001^{\text {**** }} \\
0.0022^{\text {*** }} \\
0.0051^{\text {*** }} \\
0.0041^{\text {** }} \\
0.0041^{\text {** }} \\
0.0979 \\
0.4429\end{array}$ \\
\hline
\end{tabular}

SVI: sludge volume index; HRT: hydraulic retention time; SRT: solids' residence time; DO: dissolved oxygen; T: water temperature; BOD $_{5}$ : five-day biochemical oxygen demand; TKN: total Kjeldahl nitrogen; TP: total phosphorus; C/N: chemical oxygen demand with dichromate/total Kjeldahl nitrogen; N/P: total Kjeldahl nitrogen/total phosphorus; and C/P: chemical oxygen demand with dichromate/total phosphorus.

${ }^{*} p<0.05$.

${ }^{* *} p<0.01$.

*** $p<0.001$. 
Table 4. ANOVA analysis ( $p$ values) of species abundances among different sludge volume index (SVI) levels in systems A and B.

\begin{tabular}{|c|c|c|c|c|c|c|c|c|}
\hline \multirow[t]{3}{*}{ Species } & \multicolumn{4}{|l|}{ System A } & \multicolumn{4}{|l|}{ System B } \\
\hline & \multirow[t]{2}{*}{ Global test } & \multicolumn{3}{|c|}{ Pairwise test } & \multirow[t]{2}{*}{ Global test } & \multicolumn{3}{|c|}{ Pairwise test } \\
\hline & & Low-high & Low-medium & High-medium & & Low-high & Low-medium & High-medium \\
\hline E. plicatilis & $0.0001^{* *}$ & $0.0045^{* *}$ & $0.0005^{* *}$ & 0.9622 & $0.0008^{* *}$ & $0.0015^{* *}$ & $0.0441^{*}$ & 0.2210 \\
\hline V. striata & $0.0010^{* * *}$ & $0.0162^{*}$ & $0.0086^{* *}$ & 0.7647 & $0.0000^{* *}$ & $0.0002^{* *}$ & $0.0344^{*}$ & $0.0008^{* *}$ \\
\hline C. polypinum & $0.0478^{*}$ & 0.1570 & 0.1921 & 0.7892 & $0.0001^{* *}$ & $0.0003^{* *}$ & $0.0219^{*}$ & $0.0428^{*}$ \\
\hline V. cupifera & $0.0315^{*}$ & 0.2553 & 0.0649 & 0.9960 & $0.0001^{* *}$ & $0.0018^{* *}$ & 0.9671 & $0.0011^{* *}$ \\
\hline E. sulcatum & $0.0199^{*}$ & 0.1460 & 0.0603 & 0.9702 & $0.0122^{*}$ & $0.0324^{*}$ & $0.0249^{*}$ & 0.9900 \\
\hline P. mediocanellata & $0.0432^{*}$ & 0.1575 & 0.8475 & 0.0798 & $0.0262^{*}$ & 0.3412 & $0.0205^{*}$ & 0.2728 \\
\hline
\end{tabular}

E. plicatilis: Epistylis plicatilis; V. striata: Vorticella striata; C. polypinum: Carchesium polypinum; V. cupifera: Vorticella cupifera; E. sulcatum: Entosiphon sulcatum; and P. mediocanellata: Petalomonas mediocanellata. Classification of SVI levels was based on the 48-h average SVI data: low (SVI $\leq 120 \mathrm{~mL} \mathrm{~g}^{-1}$ ); medium $\left(120 \mathrm{~mL} \mathrm{~g}^{-1}<\mathrm{SVI}<180 \mathrm{~mL} \mathrm{~g}^{-1}\right)$; and high $\left(\mathrm{SVI} \geq 180 \mathrm{~mL} \mathrm{~g}^{-1}\right)$.

* $p<0.05$.

*** $p<0.01$.

The abundances of species E. plicatilis and V. striata were closely linked to sludge settleability, in terms of SVI values (Pearson's $r \geq 0.77, p<0.001$ ), and water temperature (Pearson's $r \leq-0.71, p<0.001$ ) in both systems (Table S3). Similar but weaker links between SVI values (or water temperature) and the abundances of $C$. polypinum and V. cupifera were also observed (for SVI: Pearson's $r \geq 0.59, p<0.05$; for water temperature: Pearson's $r \leq-0.57, p<0.05$; Fig. 3 , Table S3).

On the other hand, E. sulcatum, a flagellate with saprotrophic and bactivorous feeding habits (Shen et al. 1990), was positively correlated to water temperature $\quad\left(p_{\text {System A }}=0.0019, \quad p_{\text {System B }}=0.0750\right) \quad$ and inversely correlated to some nutrient factors $\left(\mathrm{BOD}_{5}\right.$ loading: $\quad p_{\text {System A }}=0.0021, \quad p_{\text {System B }}=0.1412 ; \quad \mathrm{C} / \mathrm{N}$ : $\left.p_{\text {System A }}=0.0304, p_{\text {System B }}=0.1825\right)$. We found no correlation between the abundance of $P$. mediocanellata and environmental variables (Table S3). We have calculated
Madoni's sludge biotic index (SBI) values for all the 36 samples, as shown in Table S4 (Madoni 1994); the SBI was not found to be sensitive to sludge bulking in the present study.

\section{Discussion}

\section{Sludge bulking as the driving force for changes in microfauna community structures}

While seasonal changes of different components of the microfauna in BWTSs have been monitored by some researchers (Chen et al. 2004; Martín-Cereceda et al. 2001), microfauna community dynamics have seldom been related with sludge bulking. In this study, besides the annual cyclic changes, we observed significant differences in the community structures at different SVI levels, as shown in Figs. 1, 2
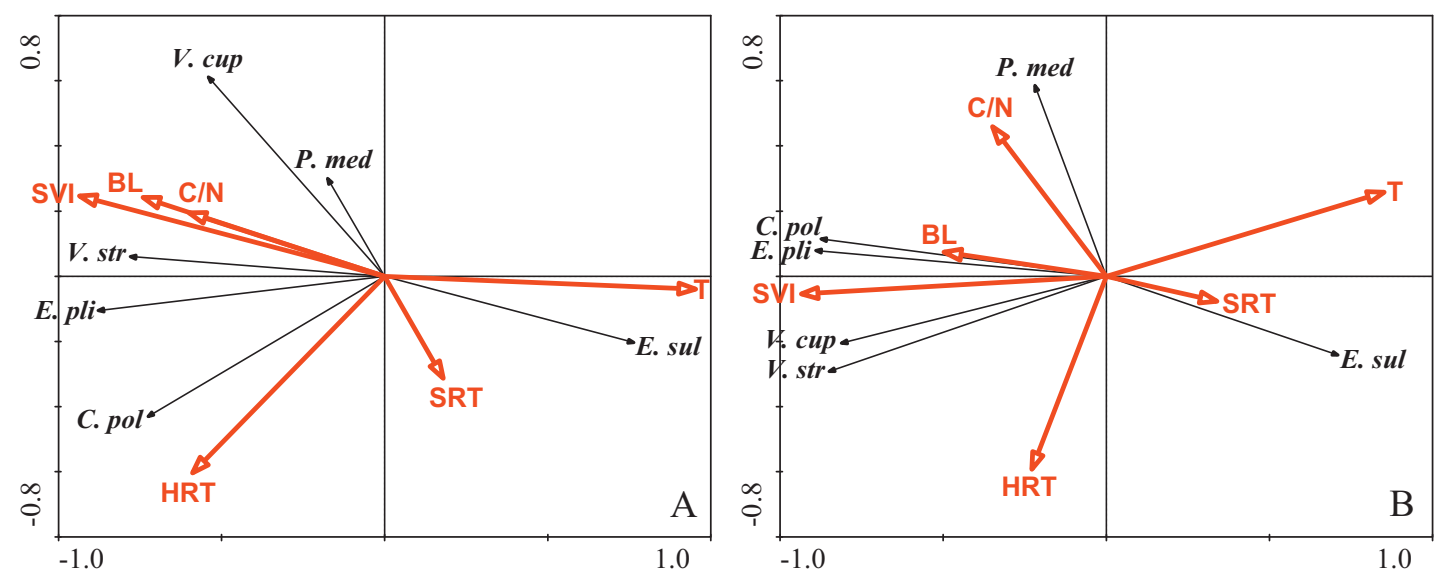

Fig. 3. RDA analysis: microfauna species-environment biplot diagrams in systems A (A) and B (B). E. pli: Epistylis plicatilis; V. str: Vorticella striata; C. pol: Carchesium polypinum; V. cup: Vorticella cupifera; E. sul: Entosiphon sulcatum; and P. med: Petalomonas mediocanellata. SVI: sludge volume index; HRT: hydraulic retention time; SRT: solids' residence time; T: water temperature; BL: five-day biochemical oxygen demand $\left(\mathrm{BOD}_{5}\right.$ ) loading; and $\mathrm{C} / \mathrm{N}$ : chemical oxygen demand with dichromate/total Kjeldahl nitrogen. 
and Table 2. Analyses of the supernatants of sludge samples with different SVI values revealed that the concentrations of monovalent $\mathrm{Na}^{+}$and $\mathrm{K}^{+}$were relatively low and stable $\left(\mathrm{Na}^{+}: 57.8-85.0 \mathrm{mg} \mathrm{L}^{-1} ; \mathrm{K}^{+}: 34.0-48.1 \mathrm{mg} \mathrm{L}^{-1}\right)$ during the study period (Fig. S1), suggesting that ion exchange of bivalent cations $\mathrm{Ca}^{2+}$ and $\mathrm{Mg}^{2+}$ for monovalent $\mathrm{Na}^{+}$and $\mathrm{K}^{+}$ ions (especially $\mathrm{Na}^{+}$), which could influence sludge aggregation, did not occur (Higgins and Novak 1997; Kara et al. 2008; Sobeck and Higgins 2002). Microscopic observations showed that Microthrix parvicella-like filaments were abundant when the SVI value was high (Fig. S2), which was also supported by a previous study focusing on bacterial community structure changes in the two systems using the PCR-DGGE technique (Hesham et al. 2011). Therefore, sludge bulking due to the abnormal growth of some filamentous bacteria was believed to be the main reason for the high SVI values in this study. Excessive growth of filaments has led to the appearance of "diffuse flocs" in the two systems (Figs. S2, S3) (Jenkins et al. 2003), which could be an important driving force for the changes in microfauna community structures.

As shown in Table 3, like the SVI index, water temperature also exhibited high correlations with the changes in microfauna community structures. The highly significant correlations between the SVI values and water temperature in the two systems (Pearson's $r_{\text {System A }}=-0.954$, $r_{\text {System B }}=-0.948 ; p<0.001$; based on the monthly average data) suggested that the low temperature regimes could be the most important influencing factor for sludge bulking in this study. The influent chemical properties, such as fatty acids, which are the favored carbon and energy sources for filamentous bacteria like M. parvicella (Rossetti et al. 2005), could be impacted by the seasonally varying water temperature. At the same time, in this study, total Kjeldahl nitrogen (TKN) in the influent was inversely correlated to water temperature (Pearson's $r_{\text {System A }}=-0.605, r_{\text {System B }}=-0.613$; $p<0.01$; based on the monthly average data), suggesting the presence of more abundant nitrogen sources in low water temperature conditions, which may also facilitate the growth of filaments of M. parvicella (Rossetti et al. 2005). It is speculated that the high correlations between water temperature and the microfauna community structures in the two systems (Table 3) may reflect the impacts of sludge bulking.

The similar correlation coefficients between the different nutrient loadings, i.e., loadings of $\mathrm{BOD}_{5}$, TKN and $\mathrm{TP}$, respectively, and the microfauna community structures $(p<0.01$; Table 3$)$ may be due to the high autocorrelations between these nutrient parameters (Pearson's $r \geq 0.912$ with an average of $0.947 ; p<0.001$; based on the monthly averaged data). Different nutrient loading and composition (e.g. $\mathrm{C} / \mathrm{N}$ ) may create particular environments favored by different microbial species, leading to changes in the microfauna community structure (Curds and Cockburn 1970; Dubber and Gray 2011; Ratsak et al. 1996).

\section{Microfauna species associated with sludge bulking}

It is known that low temperature generally reduces the physiological activities of microfauna (Finlay 1977; Sherr et al. 1988), and the optimum growth temperatures for most ciliates, including E. plicatilis and V. striata f. octava, range from $25^{\circ} \mathrm{C}$ to $30^{\circ} \mathrm{C}$ (Konstantynenko and Dovgal 2009; Shen et al. 1990; Sudo and Aiba 1971). However, as shown in Fig. 3 and Table S3, E. plicatilis, V. striata, C. polypinum and $V$. cupifera, the four peritrich ciliates feeding on small dispersed bacteria (Fenchel 1987; Madoni 2011), were all inversely related to water temperature in the range from $14.5^{\circ} \mathrm{C}$ to $26.3{ }^{\circ} \mathrm{C}$ (based on the 48 -h average data) in both systems. That is to say, the abundances of the four species, especially E. plicatilis and V. striata, increased with the decrease in water temperature, suggesting that sludge bulking may have created some favorable conditions for the growth of these species, even under a temperature condition unfavorable for their growth.

We observed diffuse sludge flocs as described by Jenkins et al. (2003) in the two systems under high SVI conditions (Fig. S3), which may have led to the release of flocculated non-filamentous bacteria to the liquor phase, as exemplified by increased levels of suspended solids in the effluents $\left(\mathrm{SS}_{\mathrm{e}}\right)\left(\right.$ Pearson's $r$ between SVI and $\mathrm{SS}_{\mathrm{e}}: r_{\text {System A }}=0.520$, $r_{\text {System B }}=0.693 ; p<0.05$; based on the 48-h average data). It is known that the four peritrich species (actually most species of bactivorous protozoa, except for crawling ciliates) can only feed on dispersed non-filamentous bacteria and particles in BWTSs (Fenchel 1987; Madoni 2011). We thus concluded that sludge de-flocculation due to the excessive growth of filamentous bacteria (e.g. M. parvicella) may have provided more suitable food for their growth.

Among the four peritrich species, E. plicatilis and V. striata (Fig. S4) were two of the three dominant peritrich ciliates in the two systems (average percentages of E. plicatilis in total peritrich ciliates: $24.3 \%$ in System A and $12.0 \%$ in System B; average percentages of V. striata: $22.8 \%$ in System A and $35.1 \%$ in System B). Another dominant peritrich ciliate was Vorticella convallaria (average percentages in total peritrich ciliates: $33.7 \%$ in System A and 31.3\% in System B), which did not significantly vary with SVI levels $(p>0.05)$ (Table S2). A similar ciliate fauna has recently been reported from a Polish wastewater treatment plant working with shock organic and ammonium loadings (Drzewicki and Kulikowska 2011). High abundances of E. plicatilis and V. striata occurred under sludge bulking conditions, while the abundance of $V$. convallaria decreased moderately after a period of sludge bulking (from samples A6 and B6 in systems A and B, respectively; sampling information shown in Table S1) (Fig. S5). The variations of the two species with the SVI changes are shown in Fig. S6. It is clear that the abundances of the two species were very low under normal sludge conditions. However, their amounts increased rapidly with the increase of SVI values. Thus, in consideration of the close associations of 
E. plicatilis and V. striata with SVI values, it may be possible to use the two species as bioindicators for sludge bulking.

\section{Acknowledgements}

This study was supported by the Chinese Academy of Sciences (No. KZCX2-YW-JC407) and the National Natural Science Foundation of China (No. 20921140094). We are grateful to Beijing Drainage Group Co., Ltd., China for provision of plant monitoring data. We thank Professor Guoji Ding from Shanghai University, China for valuable suggestions.

\section{Appendix A. Supplementary data}

Supplementary data associated with this article can be found, in the online version, at http://dx.doi.org/10.1016/ j.ejop.2013.03.001.

\section{References}

APHA, 1998. Standards Methods for the Examination of Water and Wastewater, 20th ed. American Public Health Association, Washington, DC.

Chen, S.G., Xu, M.Q., Cao, H., Zhu, J., Zhou, K.X., Xu, J., Yang, X.P., Gan, Y.P., Liu, W.Y., Zhai, J.J., Shao, Y.Y., 2004. The activated-sludge fauna and performance of five sewage treatment plants in Beijing, China. Eur. J. Protistol. 40, 147-152.

Clarke, K.R., Gorley, R.N., 2006. PRIMER v6: User Manual/Tutorial. PRIMER-E, Plymouth.

Clarke, K.R., Warwick, R.M., 2001. Change in Marine Communities: An Approach to Statistical Analysis and Interpretation, 2nd ed. PRIMER-E, Plymouth.

Curds, C.R., 1982. The ecology and role of protozoa in aerobic sewage treatment processes. Annu. Rev. Microbiol. 36, 27-46.

Curds, C.R., Cockburn, A., 1970. Protozoa in biological sewagetreatment processes - II. Protozoa as indicators in the activatedsludge process. Water Res. 4, 237-249.

Drzewicki, A., Kulikowska, D., 2011. Limitation of Sludge Biotic Index application for control of a wastewater treatment plant working with shock organic and ammonium loadings. Eur. J. Protistol. 47, 287-294.

Dubber, D., Gray, N.F., 2011. The influence of fundamental design parameters on ciliates community structure in Irish activated sludge systems. Eur. J. Protistol. 47, 274-286.

Esteban, G., Téllez, C., Bautista, L.M., 1991. Dynamics of ciliated protozoa communities in activated-sludge process. Water Res. 25, 967-972.

Fenchel, T., 1987. Ecology of Protozoa: The Biology of Free-living Phagotrophic Protists. Springer, Berlin.

Finlay, B.J., 1977. The dependence of reproductive rate on cell size and temperature in freshwater ciliated protozoa. Oecologia 30, $75-81$.

Foissner, W., Berger, H., Schaumburg, J., 1999. Identification and Ecology of Limnetic Plankton Ciliates. Bavarian State Office for Water Management, Munich.
Hesham, A.E., Qi, R., Yang, M., 2011. Comparison of bacterial community structures in two systems of a sewage treatment plant using PCR-DGGE analysis. J. Environ. Sci. 23, 2049-2054

Higgins, M.J., Novak, J.T., 1997. The effect of cations on the settling and dewatering of activated sludge: laboratory results. Water Environ. Res. 69, 215-224.

Horan, N., Lavender, P., Cowley, E., 2004. Experience of activatedsludge bulking in the UK. Water Environ. J. 18, 177-182.

Jenkins, D., Richard, M.G., Daigger, G.T., 2003. Manual on the Causes and Control of Activated Sludge Bulking, Foaming and other Solids Separation Problems, 3rd ed. CRC Press, Boca Raton, FL.

Kara, F., Gurakan, G.C., Sanin, F.D., 2008. Monovalent cations and their influence on activated sludge floc chemistry, structure, and physical characteristics. Biotechnol. Bioeng. 100, 231-239.

Konstantynenko, L.A., Dovgal, L.V., 2009. The nutrition rates of peritrichous ciliates (Ciliophora, Peritrichia) in conditions of the treatment facilities of Zhytomir (Ukraine). Natura Montenegrina 8, 51-61.

Kruit, J., Hulsbeek, J., Visser, A., 2002. Bulking sludge solved?! Water Sci. Technol. 46, 457-464.

Kudo, R.R., 1966. Protozoology, 5th ed. Charles C Thomas Publisher, Springfield, IL.

Lee, S., Basu, S., Tyler, C.W., Wei, I.W., 2004. Ciliate populations as bio-indicators at Deer Island Treatment Plant. Adv. Environ. Res. 8, 371-378.

Lepš, J., Šmilauer, P., 2003. Multivariate Analysis of Ecological Data using CANOCO. Cambridge University Press, Edinburgh.

Madoni, P., 1994. A sludge biotic index (SBI) for the evaluation of the biological performance of activated sludge plant based on the microfauna analysis. Water Res. 28, 67-75.

Madoni, P., 2011. Protozoa in wastewater treatment processes: a minireview. Ital. J. Zool. 78, 3-11.

Madoni, P., Ghetti, P.F., 1981. The structure of ciliated protozoa communities in biological sewage-treatment plants. Hydrobiologia 83, 207-215.

Martín-Cereceda, M., Pérez-Uz, B., Serrano, S., Guinea, A., 2001. Dynamics of protozoan and metazoan communities in a full scale wastewater treatment plant by rotating biological contactors. Microbiol. Res. 156, 225-238.

Martín-Cereceda, M., Serrano, S., Guinea, A., 1996. A comparative study of ciliated protozoa communities in activated-sludge plants. FEMS Microbiol. Ecol. 21, 267-276.

Martins, A.M.P., Pagilla, K., Heijnen, J.J., van Loosdrecht, M.C.M., 2004. Filamentous bulking sludge - a critical review. Water Res. 38, 793-817.

Parker, D.S., 1983. Assessment of secondary clarification design concepts. Water Environ. Res. 55, 349-359.

Patterson, D.J., 1996. Free-Living Freshwater Protozoa: A Colour Guide. Manson Publishing Ltd, London.

Pauli, W., Jax, K., Berger, S., 2001. Protozoa in wastewater treatment: function and importance. In: Beek, B. (Ed.), Biodegradation and Persistence. Springer, Berlin, pp. 203-252.

Qi, R., Yu, T., Li, Z., Li, D., Mino, T., Shoji, T., Fujie, K., Yang, M., 2012. Comparison of conventional and inverted $\mathrm{A}^{2} / \mathrm{O}$ processes: phosphorus release and uptake behaviors. J. Environ. Sci. 24, 571-578.

Ratsak, C.H., Maarsen, K.A., Kooijman, S.A.L.M., 1996. Effects of protozoa on carbon mineralization in activated sludge. Water Res. 30, 1-12. 
Rossetti, S., Tomei, M.C., Nielsen, P.H., Tandoi, V., 2005. "Microthrix parvicella", a filamentous bacterium causing bulking and foaming in activated sludge systems: a review of current knowledge. FEMS Microbiol. Rev. 29, 49-64.

Salvadó, H., Palomo, A., Mas, M., Puigagut, J., Gracia, M.P., 2004. Dynamics of nematodes in a high organic loading rotating biological contactors. Water Res. 38, 2571-2578.

Shen, Y.F., Zhang, Z.S., Gong, X.J., Gu, M.R., Shi, Z.X., Wei, Y.X., 1990. Modern Biomonitoring Techniques Using Freshwater Microbiota. China Architecture \& Building Press, Beijing.

Sherr, B.F., Sherr, E.B., Rassoulzadegan, F., 1988. Rates of digestion of bacteria by marine phagotrophic protozoa: temperature dependence. Appl. Environ. Microb. 54, 10911095.

Sobeck, D.C., Higgins, M.J., 2002. Examination of three theories for mechanisms of cation-induced bioflocculation. Water Res. $36,527-538$.

Sudo, R., Aiba, S., 1971. Growth rate of Vorticellidae isolated from activated sludge. Jpn. J. Ecol. 21, 70-76.

Sudo, R., Aiba, S., 1984. Role and function of protozoa in the biological treatment of polluted waters. Adv. Biochem. Eng. Biot. 29, 117-141.

Woombs, M., Laybourn-Parry, J., 1986. The role of nematodes in low rate percolating filter sewage treatment works. Water Res. 20, 781-787. 